\title{
Exploring the Denaturation of Whey Proteins upon Application of Moderate Electric Fields: A Kinetic and Thermodynamic Study
}

\author{
Ricardo N. Pereira, ${ }^{*}$ José A. Teixeira, and António A. Vicente \\ IBB-Institute for Biotechnology and Bioengineering, Centre for Biological Engineering, University of Minho Campus de Gualtar, \\ 4700-035 Braga, Portugal
}

Supporting Information

\begin{abstract}
Thermal processing often results in disruption of the native conformation of whey proteins, thus affecting functional properties. The aim of this work was to evaluate the effects of moderate electric fields on denaturation kinetics and thermodynamic properties of whey protein dispersions at temperatures ranging from 75 to $90{ }^{\circ} \mathrm{C}$. Application of electric fields led to a lower denaturation of whey proteins, kinetically traduced by lower values of reaction order $(n)$ and rate constant $(k)(p<0.05)$, when compared to those from conventional heating under equivalent heating rates and holding times. Furthermore, the application of electric fields combined with short come-up times has reduced considerably the denaturation of proteins during early stages of heating ( $>30 \%$ of native soluble protein than conventional heating) and has determined also considerable changes in calculated thermodynamic properties (such as $E_{\mathrm{a}} \Delta H^{\ddagger}, \Delta S^{\ddagger}$ ). In general, denaturation reactions during moderate electric fields processing were less dependent on temperature increase.
\end{abstract}

KEYWORDS: whey proteins, ohmic heating, denaturation, thermodynamic properties

\section{INTRODUCTION}

Heat denaturation of major globular whey proteins, such as $\beta$-lactoglobulin ( $\beta$-LG), $\alpha$-lactalbumin ( $\alpha$-LAC), and serum albumin, is undoubtedly of particular importance once it changes the nutritional, functional, and technological properties of its derived products, such as whey protein isolate (WPI) and whey protein concentrate (WPC). Whey protein denaturation can produce a number of undesired effects such as formation of deposits on heat exchangers, ${ }^{1,2}$ milk instability or gelling during the production of concentrated milks, ${ }^{3}$ and age-thickening of concentrated milks ${ }^{4}$ and can lead to increased rennet clotting time and low gel strength, which are unfavorable in the manufacture of cheese. 5 Therefore, the behavior of whey proteins during heating is essential for the control of their properties and characteristics during the recovery and application of whey-derived products. ${ }^{6}$ $\beta$-LG constitutes $>50 \%$ of total whey protein in bovine milk and is mainly responsible for the gelation and emulsification properties of its derivatives. This globular protein consists of 162 amino acids, including 5 cysteine (Cys) and 2 tryptophan residues. ${ }^{7}$ Under physiological conditions $\beta$-LG exists as a noncovalently linked dimer stabilized by hydrogen bonds. ${ }^{8}$ Each monomer of this globular protein has one free sulfhydryl group (Cys121), which is normally hidden in the hydrophobic interior of the protein. The tertiary structure of $\beta$-LG is strongly stabilized by two disulfide bonds (Cys66-Cys160 and Cys106-Cys119), which seem to play important roles in denaturation. 9,10

Denaturation of whey proteins is generally assumed to be a multistage process consisting of at least two steps: ${ }^{11,12}$ (1) unfolding of the native protein and (2) irreversible aggregation of unfolded protein molecules. In particular, the initial steps of the heat-induced denaturation mechanism of $\beta$-LG at neutral $\mathrm{pH}$ involve the reversible dissociation of $\beta$-LG native dimers into native monomers at a temperature above $40^{\circ} \mathrm{C}$. At a temperature close to $60^{\circ} \mathrm{C}$, the native monomers undergo an intramolecular transition into a so-called R-state, which differs from the native state only by minor conformational changes of some side chains. When the temperature of the protein solution increases above $60{ }^{\circ} \mathrm{C}$, the $\beta$-LG molecule undergoes conformational changes and partially unfolds, exposing hydrophobic amino acids and the free sulfhydryl group that are normally buried at the interface between monomers in the native protein. ${ }^{13}$ At this point, the reshuffling of intramolecular disulfide bonds may be responsible for the formation of irreversible non-native monomers with free sulfhydryl at position Cys119. ${ }^{10,14}$ Through noncovalent interactions (ionic, van der Waals, hydrophobic) and sulfhydryl/ disulfide bond exchange reactions, enabled by reactive free sulfhydryl groups (Cys121), non-native molecules of $\beta$-LG take part in the irreversible intermolecular interactions that result in the formation of aggregates. ${ }^{13,15,16}$ The occurrence and extent of these reactions can be controlled by the chemical environment ( $\mathrm{pH}$, ionic strength, fat, lactose and protein concentrations), but are extremely dependent both on heating method (direct and indirect) and heating conditions, such as temperature, heating rate, and treatment time. ${ }^{17-20}$ In this regard, the kinetics and thermodynamic parameters of the thermal denaturation of whey proteins have been studied by several authors, allowing a quantitative relationship to be established between denaturation of whey protein fractions and heat treatments applied. . $^{53,18}$

In most of the previous studies, the influence of thermal processing on the denaturation kinetics of major whey proteins

Received: $\quad$ May 2, 2011

Revised: September 19, 2011

Accepted: September 21, 2011

Published: September 21, 2011 


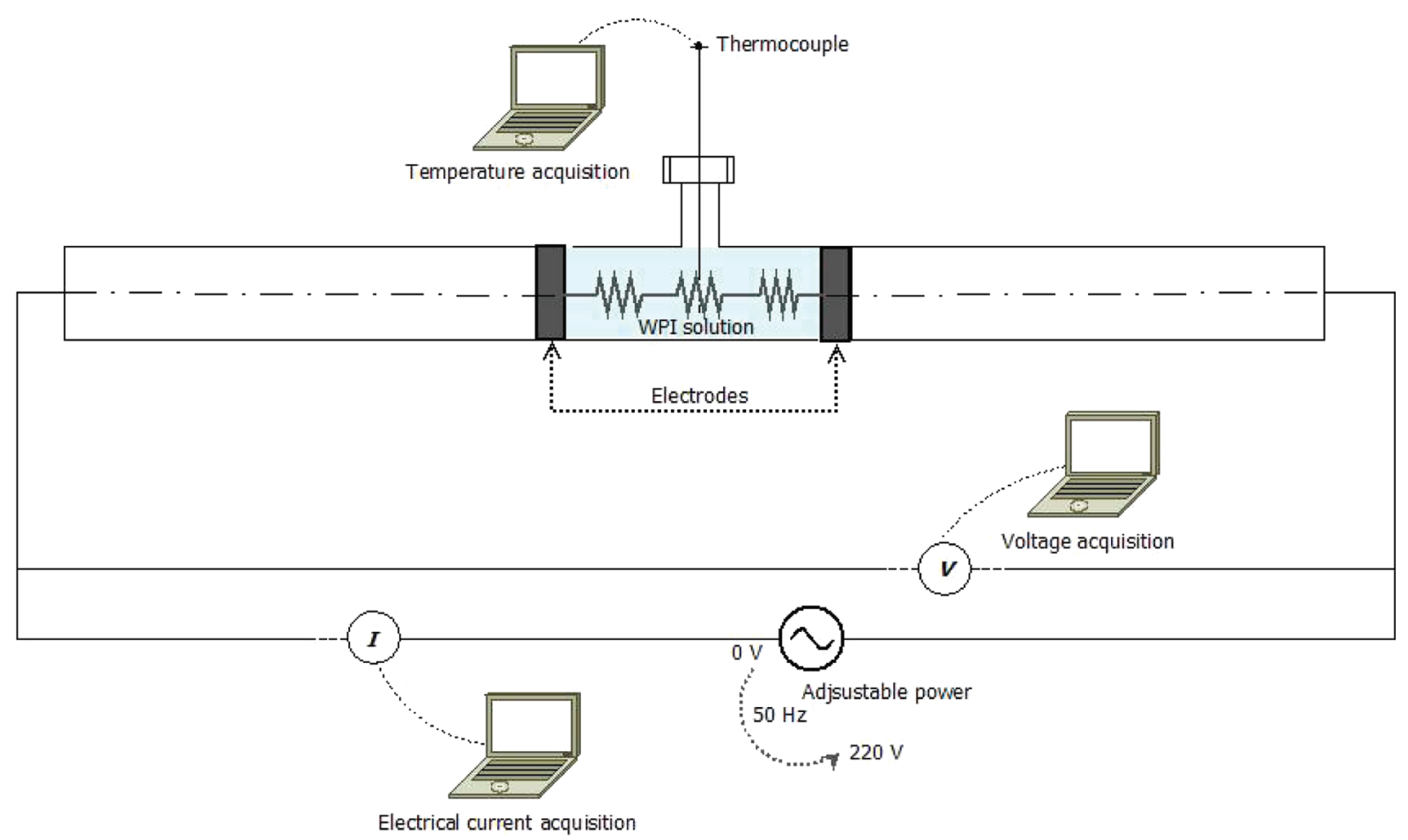

Figure 1. Batch ohmic heater and data acquisition system used for ohmic heating treatments.

has been evaluated through the use of indirect heating in water/ oil baths and laboratory-scale plate heat exchangers or by direct steam injection systems. The moderate electric fields applied during ohmic heating $(\mathrm{OH})$ are now receiving increased attention due to uniform heating of liquids and extremely rapid heating rates, which presumably enables higher temperatures to be applied without inducing coagulation or excessive denaturation of the constituent proteins. ${ }^{21} \mathrm{OH}$ is one of the earliest applications of electricity in food pasteurization and is distinguished from other electrical heating methods by (a) the presence of electrodes contacting the foods, (b) electrical treatment of low frequency when compared to microwave and radio frequency, (c) the application of unrestricted frequency, in opposition to the specially assigned radio or microwave frequency range; and (d) unrestricted waveform, although typically sinusoidal. During $\mathrm{OH}$ treatment, electric currents are passed through food a product, which behaves as a resistor in an electrical circuit, allowing generation of internal heat in agreement with Joule's law. ${ }^{22}$ Given its volumetric heating and absence of hot surfaces, $\mathrm{OH}$ technology offers the potential to overcome the limitations of slower heat transfer based on thermal conduction and, consequently, the problems associated with overheating. However, no studies are available about the influence that the application of electric fields may have on the denaturation kinetics and thermodynamic properties of whey proteins. Therefore, the objectives of this study were to (1) determine the levels of denaturation of whey protein dispersions over a wide range of temperatures, using $\mathrm{OH}$ technology; (2) compare ohmic denaturation with that obtained using a conventional heating method, under identical temperature history conditions; (3) explore the effects of fast $\mathrm{OH}$ come-up times (CUT) on the thermal denaturation of whey proteins; and (4) estimate the kinetic and thermodynamic parameters for the thermal denaturation of whey protein dispersions under all heating treatments applied.

\section{MATERIAL AND METHODS}

Whey Protein Dispersions. WPI powder (Lacprodan DI-9212) was kindly supplied by Arla Foods Ingredients (Viby, Denmark). WPI was essentially free of lactose (maximum $0.5 \%$ ) and fat (maximum $0.2 \%$ ), contained a moisture content of $6 \%$ (maximum), and had $\beta$-LG content of approximately $87 \%$, in a total protein content of $91 \%$ (of dry weight). We prepared aqueous solutions of WPI ( $3 \% \mathrm{w} / \mathrm{w}$, protein) by dispersing WPI powder in a $0.05 \mathrm{M}$ phosphate buffer of disodium hydrogen phosphate and sodium dihydrogen phosphate (Riedel de Haen, Germany) buffered to $\mathrm{pH}$ 6.0. WPI solution was then stirred continuously overnight at $5{ }^{\circ} \mathrm{C}$ to ensure full rehydration, and the $\mathrm{pH}$ was adjusted to 6.8 with $1 \mathrm{M} \mathrm{NaOH}$ (Merck, Darmstadt, Germany). Moreover, the conditions chosen, in terms of protein concentration and ionic strength, allowed an optimal starting electrical conductivity of the WPI solutions (Table S1 of the Supporting Information) for the $\mathrm{OH}$ effect to take place. WPI is used more often than isolated proteins due to cost and availability, and despite WPC being a more widespread ingredient than WPI, the study of heat-induced changes of WPC would be hindered by the presence of fat and other components. ${ }^{23}$

Heating Units. Conventional Heating (COV). Experiments were performed in a double-walled water-jacketed reactor vessel ( $3 \mathrm{~mm}$ internal diameter and $100 \mathrm{~mm}$ height). Treatment temperature was controlled by circulating water from a temperature-controlled water bath. A magnetic stirrer was introduced inside the reactor vessel to homogenize the solution and improve heat transfer during the heating cycle. Temperature evolution was measured with a type-K thermocouple (Omega 709), placed at the geometric center of the sample volume and connected to a data logger (National Instruments, USB-9161) working with Lab View 7 Express software (National Instruments, NI Data logger).

Ohmic Heating $(\mathrm{OH})$. Treatments were performed in a cylindrical glass tube of $30 \mathrm{~cm}$ total length and an inner diameter of $2.3 \mathrm{~cm}$, with two stainless steel electrodes isolated at each edge with Teflon caps (Figure 1). For the experiments, a gap between the electrodes of $10 \mathrm{~cm}$ (the treatment chamber) was used, and the supplied voltage ranged from 20 to $220 \mathrm{~V}$. The supplied voltage and, consequently, temperature were 


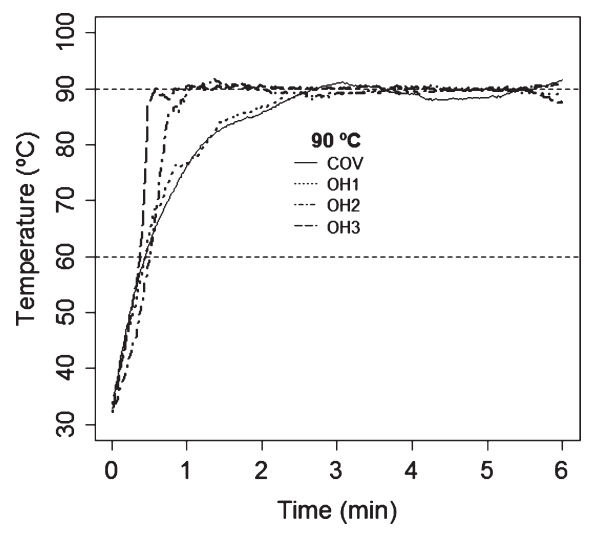

Figure 2. Example of similar thermal histories at $90{ }^{\circ} \mathrm{C}$, for conventional $(\mathrm{COV})$ and ohmic heating $(\mathrm{OH})$ treatments, using different come-up times to raise the temperature from 60 to $90{ }^{\circ} \mathrm{C}$ : $100 \mathrm{~s}(\mathrm{COV}$ and $\mathrm{OH} 1$ treatments); $37 \mathrm{~s}$ ( $\mathrm{OH} 2$ treatment); and $5 \mathrm{~s}(\mathrm{OH} 3$ treatment).

controlled through the use of a rheostat (Chuan Hsin, Taiwan) connected to the monophasic alternate current supply system $(231 \mathrm{~V}, 50 \mathrm{~Hz})$. During the experiments, the nominal electric field was varied through the rheostat to adjust the supplied voltage and simulate the thermal history of samples observed during conventional heating experiments (Figure 2). During the heating phase and holding treatment the nominal electrical field applied varied from 15 to $22 \mathrm{~V} \mathrm{~cm}^{-1}$ and from 4 to $8 \mathrm{~V} \mathrm{~cm}^{-1}$, respectively. A close coincidence of the temperature profiles during both conventional and ohmic treatments is always a necessary condition to evaluate the nonthermal effects of ohmic heating. Temperature measurement was performed as previously described for conventional heating. A data logger was employed to record continuously and simultaneously voltage and current intensity across the samples during heating.

Heat Treatments. WPI dispersions were heated through COV and $\mathrm{OH}$ at temperatures ranging from 75 to $90^{\circ} \mathrm{C}$, for various time periods (approximately 30 to $5 \mathrm{~min}$ ). After a heating CUT period (to raise the temperature from $60^{\circ} \mathrm{C}$ ), the treatment temperature was held constant (holding) for the desired time. Given the potential that $\mathrm{OH}$ has in achieving very quickly the required treatment temperatures, the influence of fast CUTs on the denaturation levels of whey protein dispersions was also evaluated. Three different CUTs were used during the experiments: $100 \mathrm{~s}$ (COV and $\mathrm{OH} 1$ treatments); $37 \mathrm{~s}(\mathrm{OH} 2$ treatment); and $5 \mathrm{~s}$ (OH3 treatment). During the holding phase, unheated (control) and heated samples $(1 \mathrm{~mL})$ were removed at appropriate time intervals and cooled immediately in ice water at $4{ }^{\circ} \mathrm{C}$ for 5 min.

Denaturation of Whey Proteins. Whey protein denaturation was followed by means of soluble tryptophan (Trp) fluorescence value $\left(F_{\text {Trp }}\right)$ at excitation/emission of $290 / 340 \mathrm{~nm}$ on the $\mathrm{pH}$ 4.6-soluble supernatant. This method is considered to be sensitive and a very rapid approach to measure the protein concentration in supernatant containing nondenatured whey proteins. ${ }^{24}$ Samples $(1 \mathrm{~mL})$ from heated (conventionally and ohmically) and unheated (control) solutions were acidified to $\mathrm{pH} 4.6$ to precipitate denatured whey proteins, by the addition of $1.0 \mathrm{~mL}$ of a $1: 1$ mixture of $0.83 \mathrm{M}$ acetic acid and $0.2 \mathrm{M}$ sodium acetate. The mixture was vigorously shaken and left for $5 \mathrm{~min}$ at room temperature. The solutions were centrifuged at $15558 \mathrm{~g}$ for $5 \mathrm{~min}$ in a Mikro 120 microfuge centrifuge (Hettich, Germany). Once the fluorescence intensity of the protein solution is proportional to the fluorophore concentration in the solution, ${ }^{25}$ the fluorescence intensity was directly proportional to WPI protein concentration in the range from 0 to $0.06 \%$. Therefore, each supernatant from WPI solution sample was diluted with distilled water before the fluorescence intensity measurements to avoid light scattering effects. ${ }^{24}$ The soluble protein concentration was calculated from a calibration curve based on the fluorescence emission of standard $\beta$-LG. Fluorescence spectra of Trp of the diluted supernatant were measured on a fluorescence spectrophotometer (Hitachi, F-4500, Tokyo, Japan) with excitation and emission monochromators at 290 and $340 \mathrm{~nm}$, respectively. Results were expressed as percentage of residual native protein $\left(P_{n}\right)$ according to eq $S 1$ of the Supporting Information.

Kinetic Analysis. Kinetic Parameters. Kinetics of whey protein denaturation was carried out by nonlinear regression (NLR) using the software R package. ${ }^{26}$ The denaturation process of WPI solutions can be described by the general rate equation (eq 1)

$$
\left(\frac{\mathrm{d} c}{\mathrm{~d} t}\right)=k_{n} C^{n}
$$

where $(\mathrm{d} c / \mathrm{d} t)$ represents the rate of protein denaturation, $k$ the rate constant, $C$ the protein concentration, and $n$ the denaturation reaction order. For reactions of order $n \neq 0$, eq 1 has as a general solution (eq 2)

$$
C_{t}=C_{0}\left[1+(n-1) k_{n} C_{0}^{n-1} t\right]^{(1 / 1-n)}
$$

where $t$ is time $(\mathrm{s}), C_{0}$ the initial protein, and $C_{t}$ the concentration $(\mathrm{g} / \mathrm{L})$ of native protein at each holding time. In eq 2 the product $k_{n} C_{0}^{n-1}$ gives an apparent rate constant $k$ with units of $\mathrm{s}^{-1}$, which is the basis of comparison between different kinetic models, circumventing the fact that $k_{n}$ has different units for different reaction orders. ${ }^{13}$ The concentration and time data were fitted directly into eq 2 , and $C_{0}, n$, and $k$ were determined simultaneously by NLR ${ }^{5,20}$ The quality of the overall fit of the model to experimental data is given by $r^{2}$. For the experimentally obtained kinetic parameters to be valid over a wide temperature range, degrees of denaturation up to $>90 \%$ have to be achieved. ${ }^{18}$

$D$ and half-time $\left(t_{1 / 2}\right)$ values, which correspond to the time required for 90 and $50 \%$ protein denaturation, respectively, were derived from eq 2 . The $z$ values, defined as the increase in temperature needed to reduce the $D$ value by $90 \%$, were calculated by regression analysis, as the reciprocal of the slope of the line obtained by plotting the logarithm of $D$ values as a function of temperature.

Thermodynamic Parameters. The apparent rate constant $k$, calculated from NLR, was related to the temperature of treatment according to the Arrhenius equation (eq S2 of the Supporting Information). When the logarithm of the rate constant was plotted against the reciprocal of the absolute temperature (according to eq S3 of the Supporting Information), the values of $E_{\mathrm{a}}$ and $\ln k_{0}$ were obtained from the slope and from the ordinate intercept, respectively. To study further the unusual effects of temperature on the denaturation reaction ${ }^{18}$ and in accordance with the activated complex theory, the Eyring equation and its relationships (eqs S4-S6 of the Supporting Information) were used. ${ }^{27}$ Thus, the changes in enthalpy of activation $\left(\Delta H^{\ddagger}\right)$, entropy of activation $\left(\Delta S^{\ddagger}\right)$, and free energy of activation $\left(\Delta G^{\ddagger}\right)$ were calculated for all temperatures.

Statistical Analysis. All statistical analyses involving experimental data were performed using $\mathrm{R}$ software version $2.10 .1 .^{26}$ Statistical significance was determined by Student's $t$ test, and the kinetic models were determined by nonlinear regression.

\section{RESULTS}

Denaturation of Whey Proteins. The extent of whey protein denaturation, on the basis of loss of solubility at $\mathrm{pH} 4.6$, was determined by $F_{\operatorname{Trp}}$. For each heating treatment, the $F_{\text {Trp }}$ value of the acidic $(\mathrm{pH} 4.6)$ protein solutions was monitored as a function of heating time. Due to the very low concentration of lactose $(<0.5 \%)$ and range of temperatures used $\left(75-90{ }^{\circ} \mathrm{C}\right)$, the $F_{\operatorname{Trp}}$ value was strictly correlated to the protein concentration during thermal denaturation. ${ }^{28}$ Changes in percentage of native whey proteins as a function of heating treatment, as well as the influence of 

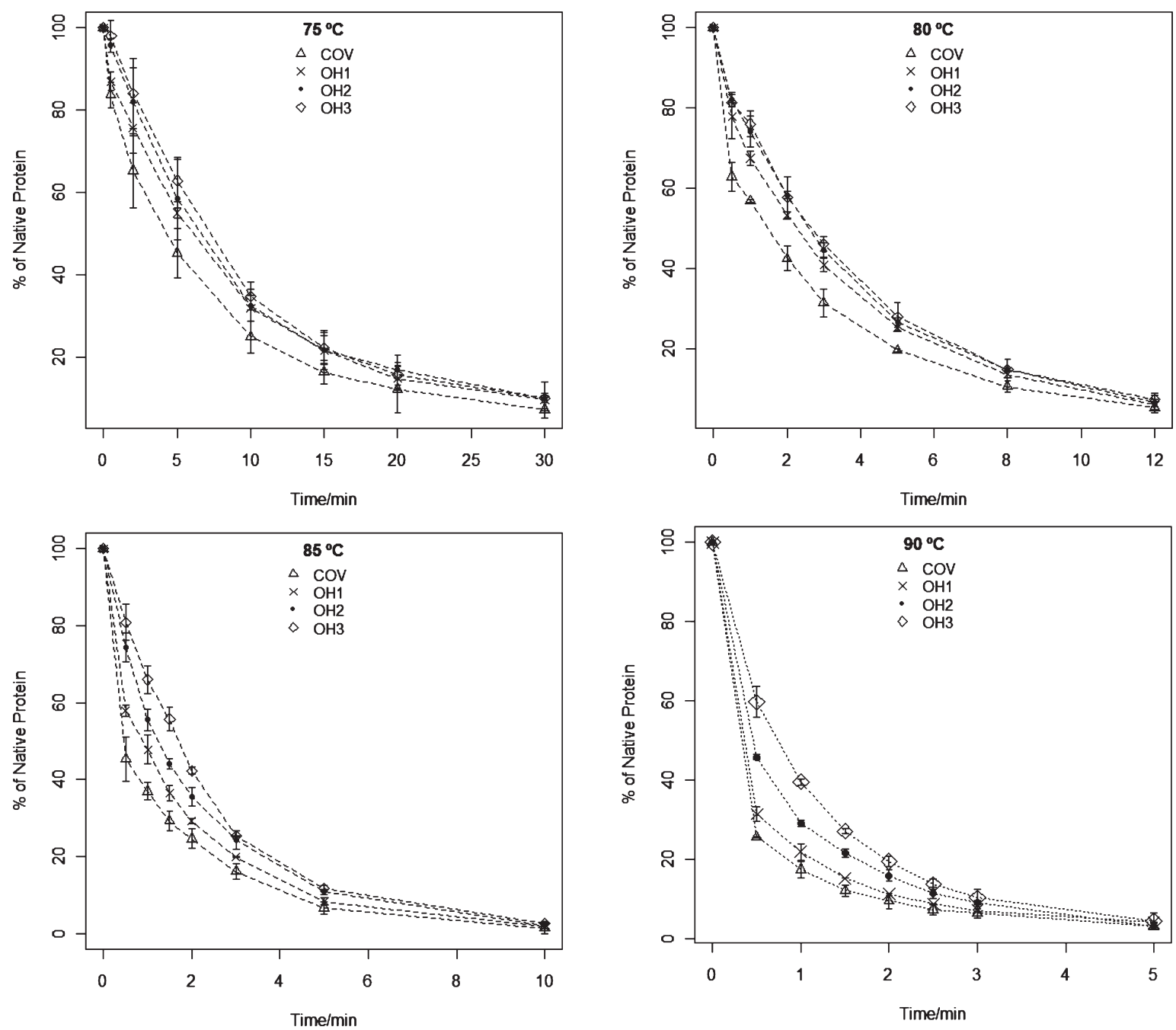

Figure 3. Level of denaturation of whey proteins, expressed as percentage of soluble native protein present in WPI solutions heated through conventional $(\mathrm{COV})$ and ohmic heating $(\mathrm{OH})$ at temperatures ranging from 75 to $90{ }^{\circ} \mathrm{C}$, using different come-up times: $100 \mathrm{~s}(\mathrm{COV}$ and $\mathrm{OH} 1$ treatments); $37 \mathrm{~s}$ (OH2 treatment); and $5 \mathrm{~s}$ (OH3 treatment).

different CUT combinations on the denaturation of whey protein solutions during $\mathrm{OH}$ are shown in Figure 3. As expected, the concentration of native whey proteins decreased with an increase in heating time and temperature, the final degrees of denaturation being all $>90 \%$ for all heating treatments applied. For equivalent heating times, the susceptibility of whey proteins to denaturation was higher under COV than under $\mathrm{OH}(p<0.05)$, particularly during the early stages of heating for treatments at temperatures $>75{ }^{\circ} \mathrm{C}$. For example, during the first $2 \mathrm{~min}$ of heating, $\mathrm{OH}$ treatments with fast $\mathrm{CUT}(\mathrm{OH} 2$ and $\mathrm{OH} 3)$ presented ca. $15-30 \%$ more native soluble protein than COV. Furthermore, the $\mathrm{OH}$ treatments that were equivalent to COV (i.e., performed under similar thermal histories) presented also 5-10\% more native soluble protein when compared with COV treatments (Figure 4).

Kinetic Analysis. The native whey protein concentration versus time data obtained at each temperature were used to determine the kinetics of whey protein denaturation. The kinetic parameters derived from NLR analysis (eq 2) are shown in Table 1. In all plots, the kinetic parameters obtained by NLR analysis were highly significant $(p<0.001)$, and their fit to the experimental data was satisfactory once all $r^{2}$ values were $>0.98$.
The order $(n)$ of denaturation reactions obtained in this wok ranged from 1 to 2.2. Several authors have already shown that in the lower temperature region $\left(<95{ }^{\circ} \mathrm{C}\right)$, the denaturation of $\beta$-LG can follow first- or second-order kinetics, presenting average reaction orders between 1.4 and $1.5 .^{17,18,20}$ The $k$ values obtained in this work ranged from 1.8 to $106 \mathrm{~s}^{-1} \times 10^{3}$ in the temperature interval of $75-90{ }^{\circ} \mathrm{C}$. These results are well comparable with published literature for the denaturation of $\beta$-LG, ${ }^{17}$ where $k$ values varied between from 0.36 and $39.63 \mathrm{~s}^{-1} \times 10^{3}$ in the temperature range of $70-85{ }^{\circ} \mathrm{C}$. Heating at $75{ }^{\circ} \mathrm{C}$ did not promote significant differences $(p>0.05)$ on kinetic parameters for the denaturation of whey protein. Otherwise, at temperatures $>75{ }^{\circ} \mathrm{C}, \mathrm{OH}$ treatments presented in general lower values of $n$ and $k(p<0.05)$ when compared to those from COV. This difference was much more pronounced for $\mathrm{OH} 2$ and $\mathrm{OH} 3$ treatments, when CUTs used at the beginning of the heating cycle ( 37 and $5 \mathrm{~s}$ ) were shorter than the one for $\mathrm{COV}$ and $\mathrm{OH} 1$ treatments $(100 \mathrm{~s})$. For treatments at 85 and $90{ }^{\circ} \mathrm{C}$, the $k$ values of $\mathrm{OH} 2$ and $\mathrm{OH} 3$ were significantly lower $(p<0.05)$ than those obtained for $\mathrm{COV}$ and $\mathrm{OH} 1$ treatments.

Kinetic parameters obtained from NLR analysis were used to determine $D$ and $t_{1 / 2}$ values, which are the times needed for 

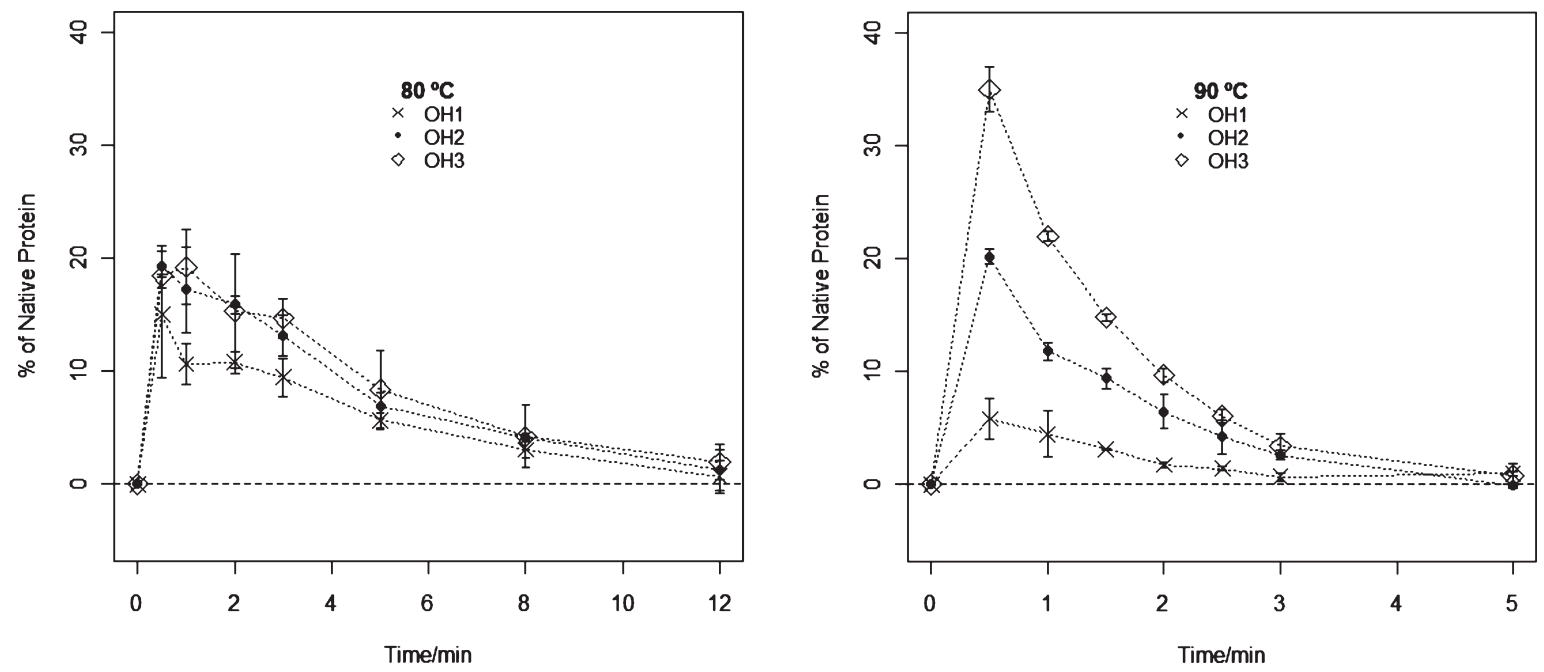

Figure 4. Relative percentage of native soluble whey protein during $\mathrm{OH}$ versus conventional heating, at temperatures of 80 and $90{ }^{\circ} \mathrm{C}$, using different CUTs: $100 \mathrm{~s}$ (OH1 treatments); $37 \mathrm{~s}$ (OH2 treatment); and $5 \mathrm{~s}$ (OH3 treatment).

Table 1. Kinetic Parameters Obtained by Nonlinear Regression (NLR) for the Denaturation of Whey Protein Isolate Solutions Subjected to Conventional (COV) and Ohmic Heating (OH) Treatments, at Temperatures Ranging from 75 to $90{ }^{\circ} \mathrm{C}^{a}$

\begin{tabular}{|c|c|c|c|c|c|c|c|}
\hline treatment & $T\left({ }^{\circ} \mathrm{C}\right)$ & $n$ & $k\left(\mathrm{~s}^{-1} \times 10^{3}\right)$ & $C_{0}\left(\mathrm{~g} \mathrm{~kg}^{-1}\right)$ & $t_{1 / 2}(\min )$ & $D(\min )$ & $r^{2}$ \\
\hline $\mathrm{COV}$ & 75 & $1.7 \pm 0.1 \mathrm{a}$ & $3.8 \pm 1.0 \mathrm{a}$ & $20.1 \pm 1.6 \mathrm{a}$ & $4.0 \pm 0.9 \mathrm{a}$ & $25.0 \pm 3.0 \mathrm{a}$ & 0.995 \\
\hline $\mathrm{OH} 1$ & & $1.4 \pm 0.3 \mathrm{a}$ & $2.3 \pm 0.2 \mathrm{a}$ & $19.8 \pm 0.1 \mathrm{a}$ & $5.9 \pm 0.1 \mathrm{a}$ & $28.8 \pm 6.6 \mathrm{a}$ & 0.996 \\
\hline $\mathrm{OH} 2$ & & $1.3 \pm 0.1 \mathrm{a}$ & $2.1 \pm 0.5 \mathrm{a}$ & $20.3 \pm 0.3 \mathrm{a}$ & $6.2 \pm 1.1 \mathrm{a}$ & $26.6 \pm 1.1 \mathrm{a}$ & 0.997 \\
\hline $\mathrm{OH} 3$ & & $1.2 \pm 0.1 \mathrm{a}$ & $1.8 \pm 0.2 \mathrm{a}$ & $20.7 \pm 1.3 \mathrm{a}$ & $6.7 \pm 0.6 \mathrm{a}$ & $25.4 \pm 1.0 \mathrm{a}$ & 0.996 \\
\hline $\mathrm{COV}$ & 80 & $2.0 \pm 0.1 \mathrm{a}$ & $13.1 \pm 1.2 \mathrm{a}$ & $19.7 \pm 2.3 \mathrm{a}$ & $1.3 \pm 0.1 \mathrm{a}$ & $11.0 \pm 2.0 \mathrm{a}$ & 0.983 \\
\hline $\mathrm{OH} 1$ & & $1.4 \pm 0.1 \mathrm{~b}$ & $6.1 \pm 0.8 \mathrm{~b}$ & $18.1 \pm 1.0 \mathrm{a}$ & $2.2 \pm 0.2 \mathrm{~b}$ & $10.5 \pm 0.7 \mathrm{a}$ & 0.992 \\
\hline $\mathrm{OH} 2$ & & $1.2 \pm 0.1 b c$ & $4.8 \pm 0.1 \mathrm{~b}$ & $19.7 \pm 2.3 \mathrm{a}$ & $2.6 \pm 0.0 \mathrm{bc}$ & $10.2 \pm 1.0 \mathrm{a}$ & 0.996 \\
\hline $\mathrm{OH} 3$ & & $1.2 \pm 0.0 \mathrm{c}$ & $4.6 \pm 0.4 b$ & $19.4 \pm 2.2 \mathrm{a}$ & $2.7 \pm 0.2 \mathrm{c}$ & $10.5 \pm 0.6 \mathrm{a}$ & 0.996 \\
\hline $\mathrm{COV}$ & 85 & $2.2 \pm 0.2 \mathrm{a}$ & $39.7 \pm 4.8 \mathrm{a}$ & $21.8 \pm 2.0 \mathrm{a}$ & $0.46 \pm 0.02 \mathrm{a}$ & $5.4 \pm 1.2 \mathrm{a}$ & 0.985 \\
\hline OH1 & & $1.7 \pm 0.1 \mathrm{~b}$ & $17.4 \pm 1.6 \mathrm{~b}$ & $22.0 \pm 2.0 \mathrm{a}$ & $0.87 \pm 0.06 \mathrm{~b}$ & $5.4 \pm 0.4 \mathrm{a}$ & 0.987 \\
\hline $\mathrm{OH} 2$ & & $1.4 \pm 0.1 \mathrm{c}$ & $11.2 \pm 1.2 \mathrm{c}$ & $21.3 \pm 2.0 \mathrm{a}$ & $1.20 \pm 0.09 c$ & $5.7 \pm 0.4 \mathrm{a}$ & 0.993 \\
\hline $\mathrm{OH} 3$ & & $1.0 \pm 0.0 \mathrm{~d}$ & $7.1 \pm 0.2 \mathrm{c}$ & $21.8 \pm 1.0 \mathrm{a}$ & $1.63 \pm 0.03 \mathrm{~d}$ & $5.4 \pm 0.1 \mathrm{a}$ & 0.998 \\
\hline $\mathrm{COV}$ & 90 & $2.2 \pm 0.1 \mathrm{a}$ & $106.0 \pm 10.2 \mathrm{a}$ & $23.0 \pm 0.3 \mathrm{a}$ & $0.17 \pm 0.01 \mathrm{a}$ & $1.9 \pm 0.2 \mathrm{a}$ & 0.999 \\
\hline $\mathrm{OH} 1$ & & $2.1 \pm 0.0 \mathrm{ab}$ & $71.8 \pm 7.4 b$ & $22.2 \pm 1.2 \mathrm{a}$ & $0.24 \pm 0.02 \mathrm{a}$ & $2.5 \pm 0.1 \mathrm{ab}$ & 0.999 \\
\hline $\mathrm{OH} 2$ & & $1.7 \pm 0.1 \mathrm{~b}$ & $33.1 \pm 1.2 \mathrm{c}$ & $21.2 \pm 0.4 \mathrm{a}$ & $0.45 \pm 0.01 \mathrm{~b}$ & $2.9 \pm 0.1 \mathrm{~b}$ & 0.998 \\
\hline $\mathrm{OH} 3$ & & $1.3 \pm 0.2 c$ & $18.4 \pm 1.8 \mathrm{c}$ & $20.5 \pm 0.2 \mathrm{a}$ & $0.71 \pm 0.03 c$ & $3.2 \pm 0.3 \mathrm{~b}$ & 0.999 \\
\hline
\end{tabular}

90 and $50 \%$ of denaturation, respectively, at constant temperature (Table 1). As expected, $D$ and $t_{1 / 2}$ values decreased with the increase of heating temperature. At temperatures of 75,80 , and $85^{\circ} \mathrm{C}$ no significant differences $(p>0.05)$ were found in $D$ values between the several treatments. However, at $90{ }^{\circ} \mathrm{C}$, the treatments $\mathrm{OH} 2$ and $\mathrm{OH} 3$ presented higher $D$ values $(p<0.05)$ than the ones from COV heating. With regard to $t_{1 / 2}$, at temperatures of $75^{\circ} \mathrm{C}$ all treatments presented nearly the same value $(p>0.05)$, whereas at temperatures ranging from 80 to $90{ }^{\circ} \mathrm{C}$, significant differences were noted $(p<0.05)$ among the treatments. Particularly, at temperatures of 80 and $85{ }^{\circ} \mathrm{C}, \mathrm{OH} 1$ treatment presented higher $t_{1 / 2}$ values than the ones obtained for COV.
Furthermore, at temperatures of 80,85 , and $90{ }^{\circ} \mathrm{C}$ treatment $\mathrm{OH} 3$ presented always the highest $t_{1 / 2}$ value $(p<0.05)$ when compared with COV and $\mathrm{OH} 1$ treatments. The logarithm of $D$ value as a function of temperature showed a linear relationship in the range of temperatures studied $\left(75-90^{\circ} \mathrm{C}\right.$ ) and allowed the calculation of $z$ values for each treatment, which were found to be between approximately 13 and $18{ }^{\circ} \mathrm{C}$ (Table 2$)$. These values are consistent with those published for $\beta$-LG heated in complex media such as raw milk. ${ }^{29} \mathrm{OH}$ treatments, in particular $\mathrm{OH} 2$ and $\mathrm{OH} 3$, showed a tendency to increase the $z$ value but without any statistical evidence $(p>0.05)$. 
Table 2. $z$ Average Values for Whey Protein Denaturation under Ohmic ( $\mathrm{OH})$ and Conventional (COV) Heating Treatments, at Temperatures Ranging from 75 to $90{ }^{\circ} \mathrm{C}^{a}$

\begin{tabular}{|c|c|c|c|}
\hline treatment & $T\left({ }^{\circ} \mathrm{C}\right)$ & $z$ value $\left({ }^{\circ} \mathrm{C}\right)$ & $r^{2}$ \\
\hline $\mathrm{COV}$ & $75-90$ & $13.4 \pm 0.5 \mathrm{a}$ & 0.999 \\
\hline $\mathrm{OH} 1$ & & $14.1 \pm 0.8 \mathrm{a}$ & 0.996 \\
\hline $\mathrm{OH} 2$ & & $16.2 \pm 1.8 \mathrm{a}$ & 0.988 \\
\hline $\mathrm{OH} 3$ & & $16.8 \pm 1.3 \mathrm{a}$ & 0.994 \\
\hline
\end{tabular}

Table 3. Free Energy of Activation $\left(E_{a}\right)$ and Pre-exponential Term $\left(k_{0}\right)$ for the Denaturation of Whey Proteins under Ohmic $(\mathrm{OH})$ and Conventional (COV) Heating Treatments, at Temperatures Ranging from 75 to $90{ }^{\circ} \mathrm{C}^{a}$

$\begin{array}{ccccc}\text { treatment } & T\left({ }^{\circ} \mathrm{C}\right) & E_{\mathrm{a}}\left(\mathrm{kJ} \mathrm{mol}^{-1}\right) & \operatorname{Ln}\left(k_{0}\right) & r^{2} \\ \mathrm{COV} & 75-90 & 232.0 \pm 11.0 \mathrm{a} & 78.9 \pm 1.9 \mathrm{a} & 0.998 \\ \mathrm{OH} 1 & & 238.4 \pm 21.0 \mathrm{a} & 80.5 \pm 5.0 \mathrm{a} & 0.992 \\ \mathrm{OH} 2 & & 185.4 \pm 8.1 \mathrm{ab} & 62.1 \pm 2.0 \mathrm{ab} & 0.998 \\ \mathrm{OH} 3 & & 154.3 \pm 19.9 \mathrm{~b} & 51.3 \pm 4.8 \mathrm{~b} & 0.984\end{array}$

${ }^{a}$ For each column means with different letters are significantly different $(p<0.05)$.

Thermodynamic Analysis. For each heating treatment, the linearity observed when the logarithm of the rate constant was plotted against the reciprocal of the absolute temperature allowed the calculation of $E_{\mathrm{a}}$ (Table 3). For COV and $\mathrm{OH} 1$, the calculated $E_{\mathrm{a}}$ values were similar $(p>0.05)$, varying from 220 to $260 \mathrm{~kJ} \mathrm{~mol}^{-1}$. These results can be compared with those reported for $\beta$-LG for temperatures between 70 and $90{ }^{\circ} \mathrm{C}, 5,17,18$ where $E_{\mathrm{a}}$ values ranging from 260 to $290 \mathrm{~kJ} \mathrm{~mol}^{-1}$ were found. However, the $E_{\mathrm{a}}$ values for $\mathrm{OH} 2$ and $\mathrm{OH} 3$ were slightly lower than the ones reported previously. In fact, $E_{\mathrm{a}}$ values obtained for $\mathrm{OH} 3$ treatment $\left(140-170 \mathrm{~kJ} \mathrm{~mol}^{-1}\right)$ differed considerably $(p<0.05)$ from the ones obtained through $\mathrm{OH} 1$ and COV.

The values of changes in enthalpy $\left(\Delta H^{\mp}\right)$, entropy $\left(\Delta S^{\ddagger}\right)$, and free energy of activation $\left(\Delta G^{\ddagger}\right)$ of the activated complex for WPI are compared in Table 4 . In accordance with transition state theory, the minimum energy necessary to allow the denaturation reaction to occur (equivalent to $E_{\mathrm{a}}$ ) was obtained through the calculation of $\Delta H^{\mp}$ using the Eyring equation and its relationships (eqs S4-S6 of the Supporting Information). The mean $\Delta H^{\ddagger}$ values followed the same tendencies observed for $E_{\mathrm{a}}$ values and were similar $(p>0.05)$ for COV and OH1. These values can be compared with those reported previously for heat-induced protein denaturation reactions of $\beta$-LG $\left(260-290 \mathrm{~kJ} \mathrm{~mol}^{-1}\right)$, at temperatures below $90{ }^{\circ} \mathrm{C}$. ${ }^{17}$ However, $\Delta H^{\ddagger}$ values for $\mathrm{OH} 3$ treatments were considerably lower than those for $\mathrm{COV}$ and $\mathrm{OH} 1$ treatments $(p<0.05)$.

The values of $\Delta S^{\neq}$were always positive, and significant differences were found among all of the treatments for each temperature $(p<0.05)$. OH1 treatment promoted higher values of $\Delta S^{\ddagger}$ (approximately $0.38 \mathrm{~kJ} \mathrm{~mol}^{-1} \mathrm{~K}^{-1}$ ) when compared with other treatments $(p<0.05)$ and lower than those reported for $\beta$-LG, ${ }^{5,18}$ which varied from 0.444 to $0.536 \mathrm{~kJ} \mathrm{~mol}^{-1} \mathrm{~K}^{-1}$. However, the lowest values of $\Delta S^{\ddagger}$ were found for $\mathrm{OH} 2\left(\sim 0.226 \mathrm{~kJ} \mathrm{~mol}^{-1} \mathrm{~K}^{-1}\right)$ and $\mathrm{OH} 3\left(\sim 0.136 \mathrm{~kJ} \mathrm{~mol}^{-1} \mathrm{~K}^{-1}\right)$ treatments. For all treatments performed, the value of $\Delta G^{\ddagger}$ remained relatively constant at
Table 4. Thermodynamic Parameters for the Denaturation of WPI Solutions Subjected to Conventional (COV) and Ohmic ( $\mathrm{OH})$ Heat Treatments, at Temperatures Ranging from 75 to $90{ }^{\circ} \mathrm{C}^{a}$

\begin{tabular}{|c|c|c|c|c|}
\hline treatment & $T\left({ }^{\circ} \mathrm{C}\right)$ & $\begin{array}{c}\Delta H^{\ddagger} \\
\left(\mathrm{kJ} \mathrm{mol}^{-1}\right)\end{array}$ & $\begin{array}{c}\Delta S^{\ddagger} \\
\left(\mathrm{kJ} \mathrm{mol}^{-1} \mathrm{~K}^{-1}\right)\end{array}$ & $\begin{array}{c}\Delta G^{\ddagger} \\
\left(\mathrm{kJ} \mathrm{mol}^{-1}\right)\end{array}$ \\
\hline $\mathrm{COV}$ & 75 & $229.1 \pm 11.0 \mathrm{a}$ & $0.365 \pm 0.002 \mathrm{a}$ & $101.9 \pm 0.8 \mathrm{a}$ \\
\hline $\mathrm{OH} 1$ & & $235.5 \pm 21.0 \mathrm{a}$ & $0.380 \pm 0.001 b$ & $103.3 \pm 0.3 \mathrm{a}$ \\
\hline $\mathrm{OH} 2$ & & $182.5 \pm 8.1 \mathrm{ab}$ & $0.227 \pm 0.002 \mathrm{c}$ & $103.6 \pm 0.7 \mathrm{a}$ \\
\hline $\mathrm{OH} 3$ & & $151.4 \pm 19.9 b$ & $0.136 \pm 0.001 \mathrm{~d}$ & $104.0 \pm 0.3 \mathrm{a}$ \\
\hline $\mathrm{COV}$ & 80 & $229.0 \pm 11.0 \mathrm{a}$ & $0.366 \pm 0.001 \mathrm{a}$ & $99.7 \pm 0.3 \mathrm{a}$ \\
\hline $\mathrm{OH} 1$ & & $235.5 \pm 21.0 \mathrm{a}$ & $0.378 \pm 0.001 b$ & $102.0 \pm 0.4 \mathrm{~b}$ \\
\hline $\mathrm{OH} 2$ & & $182.5 \pm 8.1 \mathrm{ab}$ & $0.226 \pm 0.000 \mathrm{c}$ & $102.6 \pm 0.1 \mathrm{bc}$ \\
\hline $\mathrm{OH} 3$ & & $151.3 \pm 19.9 b$ & $0.137 \pm 0.001 \mathrm{~d}$ & $102.8 \pm 0.3 \mathrm{c}$ \\
\hline $\mathrm{COV}$ & 85 & $229.0 \pm 11.0 \mathrm{a}$ & $0.366 \pm 0.001 \mathrm{a}$ & $97.9 \pm 0.4 \mathrm{a}$ \\
\hline $\mathrm{OH} 1$ & & $235.4 \pm 21.0 \mathrm{a}$ & $0.377 \pm 0.000 \mathrm{~b}$ & $100.5 \pm 0.1 \mathrm{~b}$ \\
\hline $\mathrm{OH} 2$ & & $182.5 \pm 8.1 \mathrm{ab}$ & $0.226 \pm 0.000 \mathrm{c}$ & $101.6 \pm 0.3 \mathrm{~b}$ \\
\hline $\mathrm{OH} 3$ & & $151.3 \pm 19.9 b$ & $0.134 \pm 0.001 \mathrm{~d}$ & $103.1 \pm 0.2 \mathrm{c}$ \\
\hline $\mathrm{COV}$ & 90 & $229.0 \pm 11.0 \mathrm{a}$ & $0.365 \pm 0.001 \mathrm{a}$ & $96.3 \pm 0.3 \mathrm{a}$ \\
\hline $\mathrm{OH} 1$ & & $235.4 \pm 21.0 \mathrm{a}$ & $0.380 \pm 0.001 b$ & $97.5 \pm 0.3 b$ \\
\hline $\mathrm{OH} 2$ & & $182.4 \pm 8.1 \mathrm{ab}$ & $0.227 \pm 0.000 \mathrm{c}$ & $99.8 \pm 0.1 \mathrm{c}$ \\
\hline $\mathrm{OH} 3$ & & $151.2 \pm 19.9 b$ & $0.137 \pm 0.001 \mathrm{~d}$ & $101.6 \pm 0.3 \mathrm{~d}$ \\
\hline
\end{tabular}

${ }^{a}$ For each temperature and thermodynamic parameter, means in the same column with different letters are significantly different $(p<0.05)$.

approximately $100 \mathrm{~kJ} \mathrm{~mol}^{-1}$. This value of $\Delta G^{\ddagger}$ appears to be characteristic for denaturation reactions of several food proteins, including whey proteins. ${ }^{17,30,31}$ However, at temperatures above $75^{\circ} \mathrm{C}, \Delta G^{\ddagger}$ was higher for all $\mathrm{OH}$ treatments $(\mathrm{OH} 1, \mathrm{OH} 2$, and $\mathrm{OH} 3)$ when compared to that for $\operatorname{COV}(p<0.05)$. At $90^{\circ} \mathrm{C} \Delta G^{\neq}$ was markedly different $(p<0.05)$, between all treatments, in the following order: $\mathrm{OH} 3>\mathrm{OH} 2>\mathrm{OH} 1>\mathrm{COV}$.

\section{DISCUSSION}

The present study clearly shows that $\mathrm{OH}$ potentially reduces denaturation of whey proteins during heating. In general, under identical thermal treatments, the rate of loss of native whey proteins was lower when the effect of electric field application was present. This was kinetically translated by lower $k$ and $n$ values for $\mathrm{OH}$. During $\mathrm{OH}$, heat is generated directly within the food sample (volumetric heating) and hence the problems associated with heat transfer surfaces are eliminated. ${ }^{32}$ It is also known that $\mathrm{OH}$ becomes more effective at higher temperatures, because electrical conductivity increases with the increase of temperature. Therefore, the absence of hot surfaces and less overheating may have contributed to lower rates of whey protein denaturation observed for $\mathrm{OH}$, particularly at higher temperatures $\left(>75^{\circ} \mathrm{C}\right)$. This effect was particularly evident at the early stages of heating and supported by the low values of half-denaturation times $\left(t_{1 / 2}\right)$ obtained when $\mathrm{OH}$ was applied. In contrast, for longer holding times, no significant differences were observed between ohmic and conventional protein denaturation. This was supported by identical $D$ values obtained for both treatments, for all heating temperatures ranging from 75 to $85^{\circ} \mathrm{C}$. An understanding of the thermal denaturation kinetics of whey proteins may provide 
valuable information on the initial steps of aggregation reactions, once denatured proteins are more susceptible to aggregation ${ }^{33}$ when high temperatures and long holding times are applied (Figure S1 of the Supporting Information). Therefore, results obtained in this study show that the lower levels of whey protein aggregation observed recently during $\mathrm{OH}$ experiments may have been a consequence of the lower whey protein denaturation rates occurring during the early stages of heating. ${ }^{34}$

Until the present moment, there is still no consistent information concerning nonthermal effects of $\mathrm{OH}$ on the denaturation of food proteins; the existence of nonthermal effects of $\mathrm{OH}$ has been mainly addressed in terms of microbial inactivation. ${ }^{35}$ Some evidence exists that the low frequency $(50-60 \mathrm{~Hz})$ of the ohmic treatments allows cell walls/membranes to build up charges that possibly interfere with their structure and functionality. ${ }^{36}$ The results presented here suggest that the effect of electricity on denaturation of whey proteins was not significant compared to that of heat. For example, the presence of moderate electric fields did not enhance denaturation ( $D$ values) or change $z$ values during heating. Extrinsic factors such as $\mathrm{pH}$, temperature, and ionic environment may affect molecular flexibility or stability and, consequently, protein-protein interactions. ${ }^{8,37}$ It is possible that the different associations between $\beta$-LG and other whey proteins during heating may have influenced the rate of denaturation, thus affecting the rate constants. ${ }^{20}$ Therefore, a larger body of research is still needed to evaluate if electric fields of low frequency can also dictate conformational disturbances on tertiary protein structure or distinctive interactions and associations between denatured proteins, for example.

In general, the kinetic ( $n$ and $k$ ) and thermodynamic parameters $\left(E_{a}, \Delta H^{\ddagger}, \Delta S^{\ddagger}\right.$, and $\left.\Delta G^{\ddagger}\right)$ calculated for OH1 and COV1 treatments were in good agreement with those reported in the literature for the denaturation of $\beta$-LG. This result was somehow expected, as $\beta$-LG is the most abundant protein in whey and dominates the technofunctional properties of WPI, ${ }^{38}$ which was used in this study to prepare the whey protein dispersions. The small discrepancies found between the calculated and reported kinetic/thermodynamic parameters may have been in part caused by the use of different model solutions to be heated, different protein sources, different heating methods, and/or analytical techniques. ${ }^{5,13}$ Denaturation of whey proteins is a very complex process, in which changes in the conformation of protein molecules (unfolding) are followed by irreversible aggregation reactions. Protein unfolding and aggregation are expected to have significantly different values for kinetic and thermodynamic parameters, which may allow a prediction of which of these two events is rate-determining in the reaction mechanism. ${ }^{17,18} \mathrm{~A}$ denaturation process in which the tertiary structure of the protein is disrupted to originate randomly coiled molecules involves the rupture of a large number of low-energy intramolecular bonds. This major conformational change in the protein is expressed in terms of high values for $E_{\mathrm{a}}$ or $\Delta H^{\ddagger}$ and a positive $\Delta S^{\ddagger}$, which reflects a gain in translational and rotational entropy and, consequently, a lower state of order in the molecule. In contrast, lower $E_{\mathrm{a}}$ or $\Delta H^{+}$and negative $\Delta S^{\ddagger}$ values are expected for an aggregation process in which a few intermolecular bonds are formed and the state of order of the molecules is increased. ${ }^{17,18,39}$ The thermodynamic parameters obtained in this study for $\mathrm{COV}$ and $\mathrm{OH} 1$ treatments were typical of a reaction mechanism with protein unfolding as the rate-determining process over aggregation reactions, that is, high $E_{\mathrm{a}}$ and $\Delta H^{\neq}$along with a positive $\Delta S^{\ddagger}$. These results corroborate the expected behavior in terms of aggregation and denaturation of the low protein bulk concentration solutions $(3 \% \mathrm{w} / \mathrm{w})$ used in the experiments.

Ohmic processing has enabled the heating of whey protein solutions at rapid rates through $\mathrm{OH} 2$ and $\mathrm{OH} 3$ treatments. The effect of fast CUT during $\mathrm{OH}$ on the $\beta$-LG denaturation begins to be noticeable at temperatures $>80^{\circ} \mathrm{C}$, when a change in CUT from 100 to $5 \mathrm{~s}$ decreases considerably the denaturation of whey proteins for equivalent holding times. It has already been reported that the use of fast CUTs during the heating phase in a continuous plate heat-exchanger potentially reduces the denaturation of proteins and enzymes, whereas these biochemical indicators are less affected by differences in the holding times. ${ }^{40}$ During $\mathrm{OH}$ the required temperature for HTST processes can be achieved instantaneously or at least more rapidly than with indirect heating. The use of fast CUT during $\mathrm{OH}$ may change molecular events occurring with denaturation of $\beta$-LG upon heating at temperatures up $60^{\circ} \mathrm{C}$. For example, when heat treatments of 85 or $90^{\circ} \mathrm{C}$ were applied, the time that WPI solutions were exposed at the maximum rate of thermal $\beta$-LG denaturation, which occurs at temperatures near $75^{\circ} \mathrm{C},{ }^{41}$ was shorter when $\mathrm{OH}$ was applied. Therefore, instantaneous heating combined with the absence of hot surfaces and less overheating during holding times determined not only less denaturation but also marked differences in kinetic and thermodynamic parameters obtained for denaturation reactions during OH. For example, at temperatures of $90^{\circ} \mathrm{C}$, fast CUTs have determined a considerable increase of $D$ values. Moreover, the values found for $E_{a}, \Delta H^{\ddagger}$, and $\Delta S^{\ddagger}$ when fast CUT times were used were not typical for whey protein denaturation. The unusual and weak temperature dependence observed for $\mathrm{OH} 3$ treatments is possibly a consequence of less or only partial protein denaturation, once $\Delta S^{\ddagger}$ presented a positive value indicating that the unfolding of molecules was the rate-determining step of protein denaturation over irreversible aggregation. Therefore, the low values of $E_{\mathrm{a}}$ and $\Delta S^{\ddagger}$ found for $\mathrm{OH} 3$ treatments possibly reflect less rupture of intramolecular bonds and, consequently, small changes of protein conformation during denaturation reactions.

The stability of native protein conformation upon the several treatments was also assessed by $\Delta G^{\ddagger}$, which represents the energy difference between the transition state (or activated complex) of a stepwise reaction and the ground state of the reactants. Heatinduced denaturation of $\beta$-LG at temperatures $>60{ }^{\circ} \mathrm{C}$ can be simply characterized by a three-state model that involves (1) native molecules of $\beta$-LG; (2) formation of molten globules, which are considered to be intermediates in globular protein folding and unfolding; and (3) irreversibly denatured (aggregated or polymerized) molecules. ${ }^{15}$ The molten globule state is formed as a kinetic intermediate for reversible denaturation, in equilibrium under certain mild denaturing conditions. ${ }^{42}$ The occurrence of a molten globule as an intermediate state during thermal denaturation of $\beta$-LG has been previously reported by several authors. ${ }^{16,43,44}$ Therefore, $\Delta G^{\ddagger}$ allowed the calculation of the amount of energy needed to reach the thermally induced molten globule state that precedes protein aggregation and, consequently, irreversibility of denaturation reactions. Interestingly, above $75{ }^{\circ} \mathrm{C}$ higher values of $\Delta G^{\ddagger}$ were determined for $\mathrm{OH}$ than for $\mathrm{COV}$ treatments. Furthermore, $\Delta G^{\ddagger}$ increased with the decrease of the CUT applied, particularly at high temperatures, between 85 and $90{ }^{\circ} \mathrm{C}$. Thus, more free energy of activation was needed to induce critical changes on protein conformation during $\mathrm{OH}$, particularly for treatments when fast CUTs were applied. In support of these results, it has been shown recently that $\mathrm{OH}$ seems to induce less 
formation of free reactive sulfhydryl groups when compared with COV heat treatments performed under identical thermal histories. ${ }^{34}$ It is known that the critical changes in $\beta$-LG conformation and formation of reactive intermediates involve exposure at the protein surface of both the interior hydrophobic residues and the free sulfhydryl group (Cys121) that becomes available for intermolecular interactions. ${ }^{42,45,46}$ In general, $\mathrm{OH}$ has resulted in a lower entropy gain against enthalpy upon denaturation reactions, which has consequently resulted in higher values of $\Delta G^{\ddagger}$, when compared with the ones from COV treatments. In fact, heat denaturation of whey proteins during $\mathrm{OH}$ treatments exhibited a marked thermodynamic compensation effect, ${ }^{47,48}$ once the decrease of $\Delta H^{\ddagger}$, observed for $\mathrm{OH} 2$ and $\mathrm{OH} 3$ where fast CUTs were applied, was followed by a linear decrease of $\Delta S^{\ddagger}$.

Overall, the nutritional, functional, and technological properties of milk whey proteins are changed by thermal treatments. A kinetic and thermodynamic study of protein denaturation was needed to evaluate the influence that heat treatments may exert on the final quality of commercial milk, milk-based products (such as cheese and yogurt), and whey-derived products (whey protein concentrates and isolates). As a conclusion, we have demonstrated in this work that moderate electric field processing offers the potential to reduce whey protein denaturation at relatively high temperatures during the early stages of heating. Our results suggest that the use of $\mathrm{OH}$ will clearly improve the final quality of products once the thermal treatment is less aggressive for proteins' structure. In fact, uniform heating and the absence of hot surfaces, which consequently minimize overprocessed volumes, have dictated marked differences in protein denaturation kinetics, under equivalent heating rates and holding times. Furthermore, the use of short CUTs has significantly contributed to a reduction of whey protein denaturation, giving rise to distinctive kinetic and thermodynamic parameters. The determination of these parameters provides useful information for operation of $\mathrm{OH}$ equipment; the electrical conductivity of the protein dispersions and proper electric conductance management will be essential to successfully apply $\mathrm{OH}$ and optimize the corresponding heat treatment. Ohmic technology for food processing is still being developed, modeled, and evaluated continuously. Several pieces of commercial $\mathrm{OH}$ equipment are now available from a number of suppliers for the manufacture of milk-based and other protein-rich products. ${ }^{49}$ However, $\mathrm{OH}$ technology performance and respective costs will always depend on the facility, the application of the technology, power output, considerations of product type, and the existing production equipment with which the new technology is integrated. ${ }^{50}$ However, it is believed that $\mathrm{OH}$ would still viable in a worstcase scenario because of its potential to produce superior quality products. ${ }^{51}$ Overall, the industrial implementation may offer great potential to reduce overprocessing during thermal treatments of milk and protein ingredients at thermal treatments ranging from 75 to $90{ }^{\circ} \mathrm{C}$. Further studies are needed to understand the influence that $\mathrm{OH}$ technology may have on the interfacial, aggregation, and gelation properties of whey proteins, which are intrinsically related to protein denaturation and protein-protein interactions.

\section{ASSOCIATED CONTENT}

S Supporting Information. Equations (S1-S6); Table S1 showing the characterization of unheated WPI dispersed solutions in terms of protein concentration, $\mathrm{pH}$, density, conductivity and specific heat; and Figure S1 showing an example of particle size distribution intensity curves of unheated WPI and after heating. This material is available free of charge via the Internet at http://pubs.acs.org.

\section{AUTHOR INFORMATION}

\section{Corresponding Author}

*E-mail: rpereira@deb.uminho.pt.

\section{Funding Sources}

R.N.P. gratefully acknowledges a doctoral grant (SFRH/BD/ 31635/2006) from the Fundação para Ciência e Tecnologia (FCT, Portugal).

\section{REFERENCES}

(1) Burton, H. Reviews of Progress of Dairy Science - Section G: Deposits from whole milk in heat treatment plant - a review and discussion. J. Dairy Res. 1968, 35 (2), 317-330.

(2) Fryer, P. J.; Belmar-Beiny, M. T.; Schreier, P. J. Fouling and cleaning in milk processing. In Heat-Induced Changes in Milk; Fox, P. F., Ed.; International Dairy Federation: Brussels, Belgium, 1995; pp 364-388.

(3) Singh, H.; Creamer, L. K. Heat stability of milk. In Advanced Dairy Chemistry - 1: Proteins; Fox, P. F., Ed.; Elsevier Applied Science: London, U.K.; 1992; pp 621-656.

(4) Harwalkar, V. R. Age gelation of sterilised milks. In Advanced Dairy Chemistry - 1: Proteins; Fox, P. F., Ed.; Elsevier Applied Science: London, U.K., 1992; pp 691-734.

(5) Oldfield, D. J.; Singh, H.; Taylor, M. W.; Pearce, K. N. Kinetics of denaturation and aggregation of whey proteins in skim milk heated in an ultra-high temperature (UHT) pilot plant. Int. Dairy J. 1998, 8 (4), 311-318.

(6) de la Fuente, M. A.; Singh, H.; Hemar, Y. Recent advances in the characterisation of heat-induced aggregates and intermediates of whey proteins. Trends Food Sci. Technol. 2002, 13 (8), 262-274.

(7) Kinsella, J. E.; Whitehead, D. M. Proteins in whey: chemical, physical, and functional properties. Adv. Food Nutr. Res. 1989, 33, 343-438.

(8) de Wit, J. N. Nutritional and functional characteristics of whey proteins in food products. J. Dairy Sci. 1998, 81 (3), 597-608.

(9) Kitabatake, N.; Wada, R.; Fujita, Y. Reversible conformational change in $\beta$-lactoglobulin A modified with $\mathrm{N}$-ethylmaleimide and resistance to molecular aggregation on heating. J. Agric. Food Chem. 2001, 49 (8), 4011-4018.

(10) Croguennec, T.; Bouhallab, S.; Molle, D.; O’Kennedy, B. T.; Mehra, R. Stable monomeric intermediate with exposed Cys-119 is formed during heat denaturation of $\beta$-lactoglobulin. Biochem. Biophys. Res. Commun. 2003, 301 (2), 465-471.

(11) Dewit, J. N. Thermal-stability and functionality of whey proteins. J. Dairy Sci. 1990, 73 (12), 3602-3612.

(12) Mulvihill, D. M.; Donovan, M. Whey proteins and their thermaldenaturation - a review. Irish J. Food Sci. Technol. 1987, 11 (1), 43-75.

(13) Zuniga, R. N.; Tolkach, A.; Kulozik, U.; Aguilera, J. M. Kinetics of formation and physicochemical characterization of thermally-induced $\beta$-lactoglobulin aggregates. J. Food Sci. 2010, 75 (5), E261-E268.

(14) Croguennec, T.; O'Kennedy, B. T.; Mehra., R. Heat-induced denaturation/aggregation of $\beta$-lactoglobulin $\mathrm{A}$ and $\mathrm{B}$ : kinetics of the first intermediates formed. Int. Dairy J. 2004, 14 (5), 399-409.

(15) Tolkach, A.; Kulozik, U. Reaction kinetic pathway of reversible and irreversible thermal denaturation of $\beta$-lactoglobulin. Lait 2007, 87 (4-5), 301-315.

(16) Iametti, S.; DeGregori, B.; Vecchio, G.; Bonomi, F. Modifications occur at different structural levels during the heat denaturation of $\beta$-lactoglobulin. Eur. J. Biochem. 1996, 237 (1), 106-112.

(17) Anema, S. G.; McKenna, A. B. Reaction kinetics of thermal denaturation of whey proteins in heated reconstituted whole milk. J. Agric. Food Chem. 1996, 44 (2), 422-428. 
(18) Dannenberg, F.; Kessler, H. G. Reaction-kinetics of the denaturation of whey proteins in milk. J. Food Sci. 1988, 53 (1), 258-263.

(19) Verheul, M.; Roefs, S. P. F. M.; de Kruif, K. G. Kinetics of heatinduced aggregation of $\beta$-lactoglobulin. J. Agric. Food Chem. 1998, 46 (3), 896-903.

(20) Oldfield, D. J.; Singh, H.; Taylor, M. W. Kinetics of heatinduced whey protein denaturation and aggregation in skim milks with adjusted whey protein concentration. J. Dairy Res. 2005, 72 (3), 369-378.

(21) Parrot, D. Use of ohmic heating for aseptic processing of food particulates. Food Technol. (Chicago, IL) 1992, 46 (12), 68-72.

(22) Dealwis, A. A. P.; Fryer, P. J. A finite-element analysis of heatgeneration and transfer during ohmic heating of food. Chem. Eng. Sci. 1990, 45 (6), 1547-1559.

(23) Kazmierski, M.; Corredig, M. Characterization of soluble aggregates from whey protein isolate. Food Hydrocolloids 2003, 17 (5), 685-692.

(24) Birlouez-Aragon, I.; Sabat, P.; Gouti, N. A new method for discriminating milk heat treatment. Int. Dairy J. 2002, 12 (1), 59-67.

(25) Zhang, H. K.; Li, L. T.; Tatsumi, E.; Isobe, S. High-pressure treatment effects on proteins in soy milk. Lebensm.-Wiss. -Technol.-Food Sci. Technol. 2005, 38 (1), 7-14.

(26) R Development Core Team. R: A Language and Environment for Statistical Computing; R Foundation for Statistical Computing: Vienna, Austria, 2009.

(27) Moore, W. J. Physical Chemistry, 4th ed.; Prentice Hall College: Englewood Cliffs, NJ, 1972.

(28) Birlouez-Aragon, I.; Nicolas, M.; Metais, A.; Marchond, N.; Grenier, J.; Calvo., D. A rapid fluorimetric method to estimate the heat treatment of liquid milk. Int. Dairy J. 1998, 8 (9), 771-777.

(29) Claeys, W. L.; Ludikhuyze, L. R.; Van Loey, A. M.; Hendrickx, M. E. Inactivation kinetics of alkaline phosphatase and lactoperoxidase, and denaturation kinetics of $\beta$-lactoglobulin in raw milk under isothermal and dynamic temperature conditions. J. Dairy Res. 2001, 68 (1), 95-107.

(30) Labuza, T. P. Enthalpy-entropy compensation in food reactions. Food Technol. (Chicago, IL) 1980, 34 (2), 67-77.

(31) Wehbi, Z.; Perez, M. D.; Sanchez, L.; Pocovi, C.; Barbana, C.; Calvo, M. Effect of heat treatment on denaturation of bovine $\alpha$-lactalbumin: determination of kinetic and thermodynamic parameters. J. Agric. Food Chem. 2005, 53 (25), 9730-9736.

(32) Bansal, B.; Chen, X. D.; Lin, S. X. Q. Skim milk fouling during ohmic heating. In 6th International Conference on Heat Exchanger Fouling and Cleaning - Challenges and Opportunities; Müller-Steinhagen, $\mathrm{H}$., Malayeri, R., Watkinson, A. P., Eds.; Engineering Conferences International Symposium Series: Kloster Irsee, Germany, 2005; pp 133-140.

(33) Anema, S. G.; Li, Y. Association of denatured whey proteins with casein micelles in heated reconstituted skim milk and its effect on casein micelle size. J. Dairy Res. 2003, 70 (1), 73-83.

(34) Pereira, R. N.; Souza, B. W. S.; Cerqueira, M. A.; Teixeira, J. A.; Vicente, A. A. Effects of electric fields on protein unfolding and aggregation: influence on edible films formation. Biomacromolecules 2010, 11 (11), 2912-2918.

(35) Machado, L. F.; Pereira, R. N.; Martins, R. C.; Teixeira, J. A.; Vicente, A. A. Moderate electric fields can inactivate Escherichia coli at room temperature. J. Food Eng. 2010, 96 (4), 520-527.

(36) Sastry, S. K.; Barach., J. T. Ohmic and inductive heating. J. Food Saf. 2000, 65 (s8), 42-46.

(37) Harwalker, J.; Ma, C. Y. Effects of medium composition, preheating, and chemical modification upon thermal behavior of oat globulin and $\beta$-lactoglobulin. In Food Proteins; Kinsella, J. E., Soucie, W. G., Eds.; American Oil Chemists' Society: Champaign, IL, 1989; pp $210-251$.

(38) Lefevre, T.; Subirade, M.; Pezolet, M. Molecular description of the formation and structure of plasticized globular protein films. Biomacromolecules 2005, 6 (6), 3209-3219.

(39) Yun, Z. Y.; Zhang, H. P.; Cai, X. Z.; Wang, A. P.; Zhang, L. B. Kinetic and thermodynamic studies on the thermal denaturation of bovine milk insulin-like growth factor-I in model systems. Lait 2007, 87 (2), 139-148.

(40) Villamiel, M.; LopezFandino, R.; Corzo, N.; Olano, A. Denaturation of $\beta$-lactoglobulin and native enzymes in the plate exchanger and holding tube section during continuous flow pasteurization of milk. Food Chem. 1997, 58 (1-2), 49-52.

(41) de Wit, J. N.; Swinkels., G. A. A differential scanning calorimetric study of the thermal denaturation of bovine $\beta$-lactoglobulin. Thermal behaviour at temperatures up to $100^{\circ} \mathrm{C}$. Biochim. Biophys. Acta 1980, 624 (1), 40-50.

(42) Hirose, M. Molten globule state of food proteins. Trends Food Sci. Technol. 1993, 4 (2), 48-51.

(43) Qi, X. L.; Holt, C.; McNulty, D.; Clarke, D. T.; Brownlow, S.; Jones, G. R. Effect of temperature on the secondary structure of $\beta$-lactoglobulin at $\mathrm{pH} 6.7$, as determined by $\mathrm{CD}$ and IR spectroscopy: a test of the molten globule hypothesis. Biochem. J. 1997, 324, 341-346.

(44) Carrotta, R.; Bauer, R.; Waninge, R.; Rischel, C. Conformational characterization of oligomeric intermediates and aggregates in $\beta$-lactoglobulin heat aggregation. Protein Sci. 2001, 10 (7), 1312-1318.

(45) Hoffmann, M. A. M.; vanMil, P. J. J. M. Heat-induced aggregation of $\beta$-lactoglobulin: role of the free thiol group and disulfide bonds. J. Agric. Food Chem. 1997, 45 (8), 2942-2948.

(46) Manderson, G. A.; Hardman, M.J.; Creamer, L. K. Effect of heat treatment on the conformation and aggregation of $\beta$-lactoglobulin $\mathrm{A}, \mathrm{B}$, and C. J. Agric. Food Chem. 1998, 46 (12), 5052-5061.

(47) Rhim, J. W.; Jones, V. A.; Swartzel, K. R. Kinetic compensation effect in the heat denaturation of whey-protein. J. Food Sci. 1990, 55 (2), 589.

(48) Liu, L.; Guo, Q. X. Isokinetic relationship, isoequilibrium relationship, and enthalpy-entropy compensation. Chem. Rev. 2001, 101 (3), 673-695.

(49) Leadley, C. Novel comercial preservation methods. In Biodeterioration and Preservation; Tucker, G. S., Ed.; Blackwell Publishing: Oxford, U.K., 2008; pp 211-244.

(50) Pereira, R. N.; Vicente, A. A. Environmental impact of novel thermal and non-thermal technologies in food processing. Food Res. Int. 2010, 43 (7), 1936-1943.

(51) Allen, K.; Eidman, V.; Kinsey, J. An Economic-Engineering Study of Ohmic Food Processing: Ohmic Heating for Thermal Processing of Foods: Government, Industry, and Academic Perspectives; Institute of Food Technologists: Chicago, IL, 1996; Vol. 50. 